Check for updates

Cite this: RSC Adv., 2018, 8, 6727

Received 22nd December 2017 Accepted 2nd February 2018

DOI: 10.1039/c7ra13592k

rsc.li/rsc-advances

\section{An efficient and sensitive chemosensor based on salicylhydrazide for naked-eye and fluorescent detection of $\mathrm{Zn}^{2+\dagger}$}

\begin{abstract}
Zhanglin Shi, $\$$ Yayi Tu ID $\$$ and Shouzhi Pu*
We reported here the synthesis of a diarylethene with a 2,4-dihydroxybenzoyl hydrazine moiety (10) for $\mathrm{Zn}^{2+}$ recognition. The compound is easy to prepare with a high yield up to $85 \%$. Compound 10 can act as a highly selective and specific fluorescent sensor for $\mathrm{Zn}^{2+}$ without interference by other common metal ions. The LOD for $\mathrm{Zn}^{2+}$ detection was determined to be $1.28 \times 10^{-6} \mathrm{~mol} \mathrm{~L}^{-1}$. Meanwhile, 10 can be used as a naked-eye detector for the $\mathrm{Zn}^{2+}$ ion with an obvious color change from colorless to olive. Based on the fluorescent properties of 10 , we constructed a logic circuit with four inputs of the combinational stimuli of UV/vis light and $\mathrm{Zn}^{2+} / E D T A$, and one output of fluorescence intensity.
\end{abstract}

\section{Introduction}

As we all know, zinc(II) is the second most abundant and essential element after iron ions $\left(\mathrm{Fe}^{2+}\right.$ and $\left.\mathrm{Fe}^{3+}\right)$ in the human body and performs a variety of functions..$^{1-3}$ It is an integral part of numerous enzymes and plays a critical role in various biological processes, such as protein metabolism, the immune system, gene transcription and regulation. ${ }^{4-7}$ The research on $\mathrm{Zn}^{2+}$ has drawn considerable attention among biologists, chemists, environmentalists and pharmacologists for its chemical and physical properties. The concentration of $\mathrm{Zn}^{2+}$ in the human body ranges from nanomolar (nM) to millimolar $(\mathrm{mM})^{8}$ and it is indispensable to living organisms. Depletion of biological $\mathrm{Zn}^{2+}$ leads to a decrease in wound health strength as a result of impaired collagen synthesis. ${ }^{9} \mathrm{Zn}^{2+}$ is a relatively nontoxic element, while its high level is cytotoxic. Unbalanced metabolism of $\mathrm{Zn}^{2+}$ may lead to a series of diseases, such as Alzheimer's disease,${ }^{10}$ Parkinson's disease,${ }^{11}$ diabetes, ${ }^{12}$ prostate cancer $^{\mathbf{1 3}}$ and immune dysfunction. ${ }^{\mathbf{1 4}}$ It is important for us to maintain the balance of $\mathrm{Zn}^{2+}$ in human body. Therefore, monitoring the distribution and concentration of $\mathrm{Zn}^{2+}$ in environmental or biologic samples becomes important.

The demand for chemosensors that are selective and sensitive for specific target ion is continuously increasing. Numerous sensitive detection methods for metal ion recognition have been widely used in the field of analytical chemistry, biology and environmental processes,${ }^{15-18}$ such as mass spectrometry,

Jiangxi Key Laboratory of Organic Chemistry, Jiangxi Science and Technology Normal University, Nanchang, Jiangxi 330013, PR China. E-mail: pushouzhi@tsinghua.org.cn; Fax: +86-791-83831996; Tel: +86-791-83831996

$\dagger$ Electronic supplementary information (ESI) available. See DOI: $10.1039 / \mathrm{c} 7 \mathrm{ra13592 \textrm {k }}$

\$ These authors contributed equally to this work. atomic absorption spectroscopy and high performance liquid chromatography. However, these methods are laborious and require the use of complex equipment. Fluorescence is a powerful tool to detect target ions for its simplicity, easy implementation, high sensitivity and low detection limit. ${ }^{19-21}$ When a specific fluorescent chemosensor is added to a solution of target metal ion, a color change can be observed accompanied by the changes of fluorescent characteristics. Based on this apparent phenomenon, we can design efficient chemosensors for the recognition of specific ions.

Over the years, many fluorescent chemosensors have been reported for the detection of $\mathrm{Zn}^{2+}$. Several $\mathrm{Zn}^{2+}$ sensors have been developed based on different fluorophores, such as quinoline, ${ }^{22-24}$ fluorescein, ${ }^{25-28}$ coumarin, ${ }^{29-32}$ peptide, ${ }^{33}$ and pyrene. ${ }^{34}$ However, most of them lack the smartness in $\mathrm{Zn}^{2+}$ selectivity, sensitivity and interference resistance from $\mathrm{Cd}^{2+}$ ion, ${ }^{35,36}$ or there is a low yield resulting from complex purification protocols. ${ }^{37-39}$ As shown in Table 1, most of these sensors can not distinguish $\mathrm{Zn}^{2+}$ from $\mathrm{Cd}^{2+} .^{40-44} \mathrm{Zn}^{2+}$ and $\mathrm{Cd}^{2+}$ are located in the same group of the periodic table and show similar photo-physical changes in these sensors. ${ }^{45}$ So, an active search of new analytic agents with higher sensitivity and selectivity for $\mathrm{Zn}^{2+}$ continues at the present time.

Photo-stimuli responsive materials have attracted much attention due to their potential applications in optical devices, controlled release, clean energy, sensors, etc. Until now, plenty of materials based on different photoactive groups have been explored. Spiropyran, spirooxazine, diarylethene and fulgide derivatives are photochromic materials based on photo-induced isomerization involving ring-opening/closing reactions. ${ }^{\mathbf{4 6 , 4 7}}$ Photochromism refers to a reversible change in the properties of a molecule in response to light. Among the various photochromic compounds, diarylethenes are gaining increasing attention in the field of photo-electronics, such as optical 
Table 1 Comparative study of the analytical performance of 10 with other reported sensors

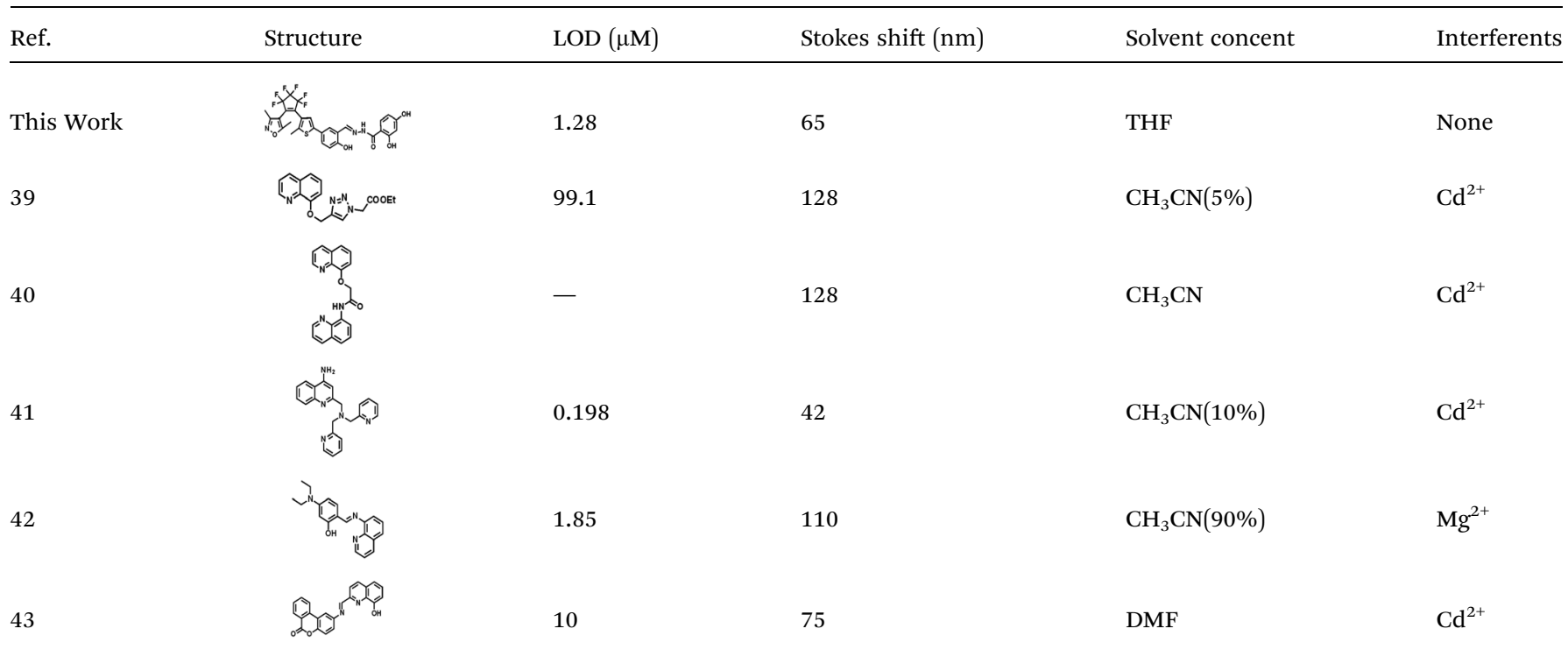

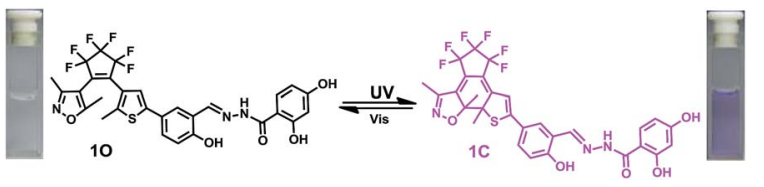

Scheme 1 Synthesis route to diarylethene 10

memory media and photo-switching devices, due to their high thermal stability, excellent fatigue resistance, and characteristic bistability. ${ }^{48,49}$

In the current work, we reported a $\mathrm{Zn}^{2+}$ chemosensor with a 2,4-dihydroxybenzoyl hydrazine unit. Salicylhydrazide is one of the important members in Schiff base family because it offers a number of possibilities for different modes of coordination with transition metal ions. ${ }^{50,51}$ On the other side, considering the advantages of fast response and excellent thermal stability for diarylethene derivatives, we designed and synthesized the compound 10. The chemosensor detected $\mathrm{Zn}^{2+}$ with high selectivity and specificity accompanied by obvious color changes by stimuli of lights and metal ions. Besides, addition of $\mathrm{Zn}^{2+}$ into the compound $\mathbf{1 0}$ resulted in a change in the absorbance spectra, making 10 a naked-eye detector for $\mathrm{Zn}^{2+}$. The photochromic process of the diarylethene derivate was shown in Scheme 1.

\section{Experimental}

\section{General methods}

All solvents were of analytical purity and were purified by distillation before use. Other reagents were used without further purification. Mass spectra were measured with a Bruker amazon SL Ion Trap Mass spectrometer. ${ }^{1} \mathrm{H}$ NMR and ${ }^{13} \mathrm{C}$ NMR spectra were recorded on a Bruker AV400 (400 MHz) spectrometer with tetramethylsilane as an internal standard.
Infrared spectra (IR) were recorded on a Bruker Vertex-70 spectrometer. Melting point was measured on a WRS-1B melting point apparatus. Fluorescence spectra were measured using a Hitachi F-4600 spectrophotometer. The fluorescence quantum yield was measured with an Absolute PL Quantum Yield Spectrometer QY C11347-11. Absorption spectra were measured using an Agilent $8453 \mathrm{UV} / \mathrm{vis}$ spectrophotometer with an MUL-165 UV lamp and a MVL-210 visible lamp as equipments of photoirradiation. The solutions of metal ions $\left(0.1 \mathrm{~mol} \mathrm{~L}^{-1}\right)$ were prepared by the dissolution of their respective metal nitrates in distilled water, except for $\mathrm{K}^{+}, \mathrm{Ba}^{2+}, \mathrm{Mn}^{2+}$, and $\mathrm{Hg}^{2+}$ (all of their counter ions were chloride ions). Necessary dilutions were made according to each experimental set up. All of the measurements were conducted at room temperature unless otherwise stated.

\section{Synthesis of 10}

Diarylethene 10 was synthesized as presented in Scheme 2. Compound 2 was synthesized according to the previous reported similar method.$^{58}$ Compound $2(0.25 \mathrm{~g}, 0.5 \mathrm{mmol})$ and 2,4-dihydroxybenzoyl hydrazine $(0.1 \mathrm{~g}, 0.6 \mathrm{mmol})$ were dissolved in a round-bottom flask with ethanol $(20 \mathrm{~mL})$. After refluxed for $4 \mathrm{~h}$ until no compound 2 was detected by the TLC silica gel plate. The mixture was cooled to room temperature and concentrated under vacuum. The crude product was purified by recrystallization with ethanol to give compound $\mathbf{1 0}$ $(0.29 \mathrm{~g}, 0.46 \mathrm{mmol})$ as a white solid in $83 \%$ yield. Mp $458-459 \mathrm{~K}$;

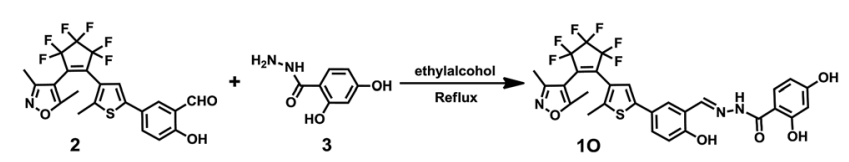

Scheme 2 Synthesis route to diarylethene 10 
${ }^{1} \mathrm{H}$ NMR (400 MHz, DMSO- $d_{6}$, TMS), $\delta$ (ppm): 2.00 (s, 3H), 2.06 $(\mathrm{s}, 3 \mathrm{H}), 2.28(\mathrm{~s}, 3 \mathrm{H}), 6.35(\mathrm{~s}, 1 \mathrm{H}), 6.40(\mathrm{~d}, 1 \mathrm{H}, J=8.0 \mathrm{~Hz}), 7.01(\mathrm{~d}$, $1 \mathrm{H}, J=8.0 \mathrm{~Hz}), 7.39(\mathrm{~s}, 1 \mathrm{H}), 7.57-7.60(\mathrm{~m}, 1 \mathrm{H}), 7.82(\mathrm{~d}, 2 \mathrm{H}, J=$ $8.0 \mathrm{~Hz}), 8.69(\mathrm{~s}, 1 \mathrm{H}), 10.33(\mathrm{~s}, 1 \mathrm{H}), 11.45(\mathrm{~s}, 1 \mathrm{H}), 11.96(\mathrm{~s}, 1 \mathrm{H})$, 12.19 (s, 1H). (Fig. S1, ESI $\dagger$ ) ${ }^{13} \mathrm{C}$ NMR (DMSO- $d_{6}, 100 \mathrm{MHz}$ ): $10.13,11.69,13.98,102.70,102.87,103.93,107.06,107.62$, 117.29, 119.40, 121.33, 124.05, 124.12, 125.75, 128.57, 129.87, 140.42, 141.81, 147.25, 157.44, 157.06, 162.04, 162.87, 170.16. (Fig. S2, ESI $\dagger$ ) IR $\left(\mathrm{KBr}, \nu, \mathrm{cm}^{-1}\right): 601,982,1064,1136,1279$, 1612, 3255. (Fig. S3, ESI $\dagger$ ). HR-MS (ESI, $m / z):[\mathrm{M}-\mathrm{H}]^{-}$calcd for $\left(\mathrm{C}_{29} \mathrm{H}_{20} \mathrm{~F}_{6} \mathrm{~N}_{3} \mathrm{O}_{5} \mathrm{~S}\right)^{-}$, 636.1028; found 636.1034 (Fig. S4, ESI $\dagger$ ).

\section{Results and discussion}

\section{Photochromic and fluorescent behaviors}

The absorption spectrum and fluorescence changes of 10 were measured in tetrahydrofuran $\left(2.0 \times 10^{-5} \mathrm{~mol} \mathrm{~L}^{-1}\right)$ at room temperature. As shown in Fig. 1, the absorption maximum of $\mathbf{1 0}$ was observed at $312 \mathrm{~nm}\left(\varepsilon=4.30 \times 10^{4} \mathrm{~mol}^{-1} \mathrm{~L} \mathrm{~cm}^{-1}\right)$, which was resulted from $\pi-\pi^{*}$ transition. ${ }^{52}$ On irradiation with $297 \mathrm{~nm}$ light, a new absorption band centered at $565 \mathrm{~nm}(\varepsilon=$ $3.29 \times 10^{3} \mathrm{~mol}^{-1} \mathrm{~L} \mathrm{~cm}^{-1}$ ) appeared and the color of 10 solution turned purple due to the formation of closed-ring isomer 1C. At the same time, the absorption band peaked at $312 \mathrm{~nm}$ decreased gradually. Reversely, the purple solution could be completely bleached upon irradiation with visible light $(\lambda>500$ $\mathrm{nm}$ ) and its absorption spectrum recovered to that of the openring isomer 10. Fig. $\mathrm{S} 5 \dagger$ showed the emission spectral changes of 10 by alternating irradiation with UV and visible light. When excited with $365 \mathrm{~nm}$ light, an emission peak of 10 was observed at $580 \mathrm{~nm}$. The fluorescence quantum yield of 10 was determined to be 0.006. On irradiation with $297 \mathrm{~nm}$ light, the photocyclization happened and its emission intensity decreased slightly due to the formation of non-fluorescent closed-ring isomer 1C. The fluorescence quantum yield of $\mathbf{1 C}$ was determined to be 0.004 . The emission intensity of $\mathbf{1 0}$ was quenched to $c a .80 \%$ at the photostationary state. This phenomenon indicated that the diarylethene unit exhibited relatively low fluorescent modulation efficiency in tetrahydrofuran and it would provide a low background when act as a $\mathrm{Zn}^{2+}$ sensor. The residual fluorescence in the photostationary state might be attributed to the incomplete cyclization reaction and existence of parallel conformations. ${ }^{53,54}$ Back irradiation with appropriate wavelength visible light regenerated its opening isomer and recovered the original emission intensity.

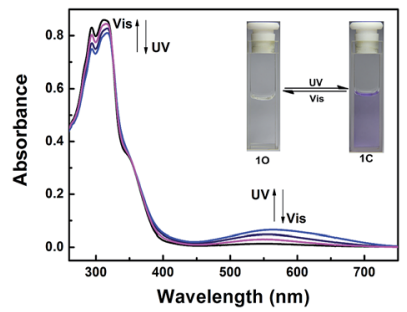

Fig. 1 Absorption spectra and color changes of 10 by photoirradiation.

\section{Absorption changes induced by $\mathrm{Zn}^{2+} /$ EDTA and UV/vis light}

The absorption property of $\mathbf{1 0}$ was investigated in tetrahydrofuran $\left(2.0 \times 10^{-5} \mathrm{~mol} \mathrm{~L}^{-1}\right)$ at room temperature. As shown in Fig. $2 \mathrm{~A}$, when different metal ions (5 equiv. $0.1 \mathrm{~mol} \mathrm{~L}^{-1}$ ) were added to the solution of 10 , including $\mathrm{Zn}^{2+}, \mathrm{Al}^{3+}, \mathrm{Fe}^{3+}, \mathrm{Cr}^{3+}, \mathrm{K}^{+}$, $\mathrm{Ba}^{2+}, \mathrm{Ca}^{2+}, \mathrm{Ni}^{2+}, \mathrm{Mg}^{2+}, \mathrm{Mn}^{2+}, \mathrm{Cd}^{2+}, \mathrm{Sr}^{2+}, \mathrm{Co}^{2+}, \mathrm{Pb}^{2+}$ and $\mathrm{Ag}^{+}$, the absorption spectral had no obvious changes except $\mathrm{Zn}^{2+}, \mathrm{Ni}^{2+}$ and $\mathrm{Co}^{2+}$. New absorption bands centered at $408 \mathrm{~nm}(\varepsilon=2.09 \times$ $\left.10^{4} \mathrm{~mol}^{-1} \mathrm{~L} \mathrm{~cm}^{-1}\right), 438 \mathrm{~nm}\left(\varepsilon=1.25 \times 10^{4} \mathrm{~mol}^{-1} \mathrm{~L} \mathrm{~cm}^{-1}\right)$ and $420 \mathrm{~nm}\left(\varepsilon=1.60 \times 10^{4} \mathrm{~mol}^{-1} \mathrm{~L} \mathrm{~cm}^{-1}\right)$ were observed respectively. The colorless 10 solution turned olive on addition of $\mathrm{Zn}^{2+}, \mathrm{Ni}^{2+}$ and $\mathrm{Co}^{2+}$ over other metal ions (Fig. 2E). The above results indicated that $\mathbf{1 0}$ could be used as a detective colorimetric sensor for $\mathrm{Zn}^{2+}$. But the selectivity is not so good with the interference of $\mathrm{Ni}^{2+}$ and $\mathrm{Co}^{2+}$.

Under the same experiment conditions, we studied the optimal algorithm of 10 induced by $\mathrm{Zn}^{2+}$ and UV/vis light. As shown in Fig. 2B, with the addition of 26 equiv. of $\mathrm{Zn}^{2+}$ $\left(0.1 \mathrm{~mol} \mathrm{~L}^{-1}\right)$ to the solution of 10 , a new absorption band centered at $408 \mathrm{~nm}$ appeared with the concomitant color change from colorless to olive due to the formation of $10-\mathrm{Zn}^{2+}$ complex $\left(\mathbf{1 0}^{\prime}\right)$ with a much steadier rigid construction than $\mathbf{1 0}$. When $\mathrm{Zn}^{2+}$ was added to the solution of $1 \mathrm{C}$, the absorbance at $410 \mathrm{~nm}\left(\varepsilon=1.88 \times 10^{4} \mathrm{~mol}^{-1} \mathrm{~L} \mathrm{~cm}^{-1}\right)$ increased, at the same time, the $565 \mathrm{~nm}$ absorbance was red-shifted by $35 \mathrm{~nm}$ (Fig. 2C). The phenomena might be on account of formation of the 1C$\mathrm{Zn}^{2+}$ complex $\left(\mathbf{1 C}^{\prime}\right)$. Then, by addition of excess EDTA $\left(0.1 \mathrm{~mol} \mathrm{~L}^{-1}\right)$ to the solution of $\mathbf{1 0}^{\prime}$ or $\mathbf{1 \mathbf { C } ^ { \prime }}$, the absorption band all recovered to 10 or $1 \mathrm{C}$ because EDTA possibly stripped $\mathrm{Zn}^{2+}$ away from the cavity by the binding zone. Furthermore, as shown in Fig. 2D, when the maximum absorption band of $\mathbf{1 0}^{\prime}$ was reached, upon irradiation with $297 \mathrm{~nm}$ UV light, a new
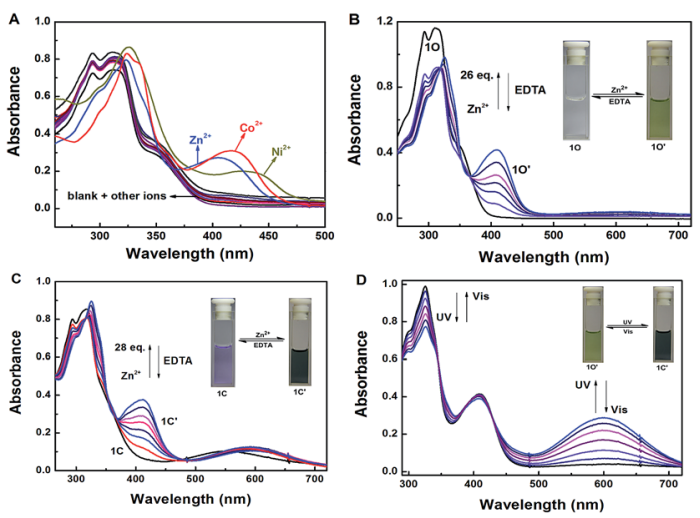

E

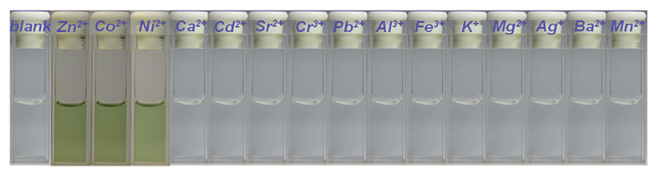

Fig. 2 Changes in absorption spectra and color of 10 induced by $\mathrm{Zn}^{2+} /$ EDTA and light in tetrahydrofuran $\left(2.0 \times 10^{-5} \mathrm{~mol} \mathrm{~L}^{-1}\right)$ : (A) changes in absorption spectra on addition of different metal ions (B) 10 induced by $\mathrm{Zn}^{2+} /$ EDTA, (C) $1 \mathrm{C}$ induced by $\mathrm{Zn}^{2+} /$ EDTA, (D) $10^{\prime}$ induced by UV/vis light, (E) color changes on addition of different metal ions. 
absorption band appeared clearly which centered at $600 \mathrm{~nm}(\varepsilon=$ $1.44 \times 10^{4} \mathrm{~mol}^{-1} \mathrm{~L} \mathrm{~cm}^{-1}$ ) and the color changed from olive to dark slate gray for the formation of the closed-ring isomer $\mathbf{1 C}^{\prime}$. Meanwhile, it could return back to the open-ring isomer $\mathbf{1 0}^{\prime}$ on irradiation with visible light $(\lambda>500 \mathrm{~nm})$, indicating that the open-ring isomer $\mathbf{1 0}^{\prime}$ and the closed-ring isomer $\mathbf{1}^{\prime}$ reaction was reversible.

\section{Fluorescence response to metal ions}

Under the same experimental conditions, Fig. 3 showed the emission spectral and fluorescence color changes of $\mathbf{1 0}$ induced by various metal ions ( 5 equiv. $0.1 \mathrm{~mol} \mathrm{~L}^{-1}$ ) such as $\mathrm{Zn}^{2+}, \mathrm{Al}^{3+}$, $\mathrm{Fe}^{3+}, \mathrm{Cr}^{3+}, \mathrm{K}^{+}, \mathrm{Ba}^{2+}, \mathrm{Ca}^{2+}, \mathrm{Ni}^{2+}, \mathrm{Mg}^{2+}, \mathrm{Mn}^{2+}, \mathrm{Cd}^{2+}, \mathrm{Sr}^{2+}, \mathrm{Co}^{2+}, \mathrm{Pb}^{2+}$ and $\mathrm{Ag}^{+}$. We found that $\mathbf{1 0}$ can detect $\mathrm{Zn}^{2+}$ in tetrahydrofuran $\left(2.0 \times 10^{-5} \mathrm{~mol} \mathrm{~L}^{-1}\right)$. The fluorescence of 10 was notably changed when $\mathrm{Zn}^{2+}$ was added, while the addition of other cations caused no obvious changes (Fig. 3A). When $\mathrm{Zn}^{2+}$ was added to the solution of $\mathbf{1 0}$, the fluorescence intensity was enhanced evidently and the emission peak was blue shifted from $580 \mathrm{~nm}$ to $515 \mathrm{~nm}$ with a concomitant fluorescent color change from dark to bright aliceblue caused by the formation of $\mathbf{1 0}^{\prime}$. The

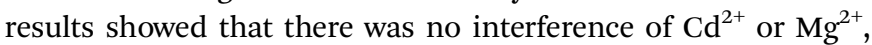
indicating good selectivity of $\mathrm{Zn}^{2+}$. Therefore, $\mathbf{1 0}$ can be used as an efficient fluorescence chemosensor for $\mathrm{Zn}^{2+}$ recognition.

To further evaluate the responsive nature of $\mathbf{1 0}$ induced by $\mathrm{Zn}^{2+}$, a series of fluorescence titration tests were carried out in tetrahydrofuran $\left(2.0 \times 10^{-5} \mathrm{~mol} \mathrm{~L}^{-1}\right)$ at room temperature. When $\mathrm{Zn}^{2+}$ was added to the solution of $\mathbf{1 0}$ from 0 to 18 equiv., the fluorescence intensity increased significantly with a blue shift of $65 \mathrm{~nm}$ from $580 \mathrm{~nm}$ to $515 \mathrm{~nm}$ (Fig. 4A). The titration experiment was shown in Fig. S6. $\dagger$ Compared with 10, the fluorescence intensity was enhanced by 31 fold. The increased emission intensity and blue shift could be ascribed to the formation of $\mathbf{1 0}^{\prime}$. The fluorescent quantum yield of $\mathbf{1 0}^{\prime}$ was determined to be 0.044 . The stable chelation of $\mathbf{1 0}$ with $\mathrm{Zn}^{2+}$ inhibited the $\mathrm{C}=\mathrm{N}$ isomerization and led to a rigid fluorophore structure, causing enhanced fluorescence intensity. ${ }^{55,56}$ The fluorescence spectrum of $\mathbf{1 0}^{\prime}$
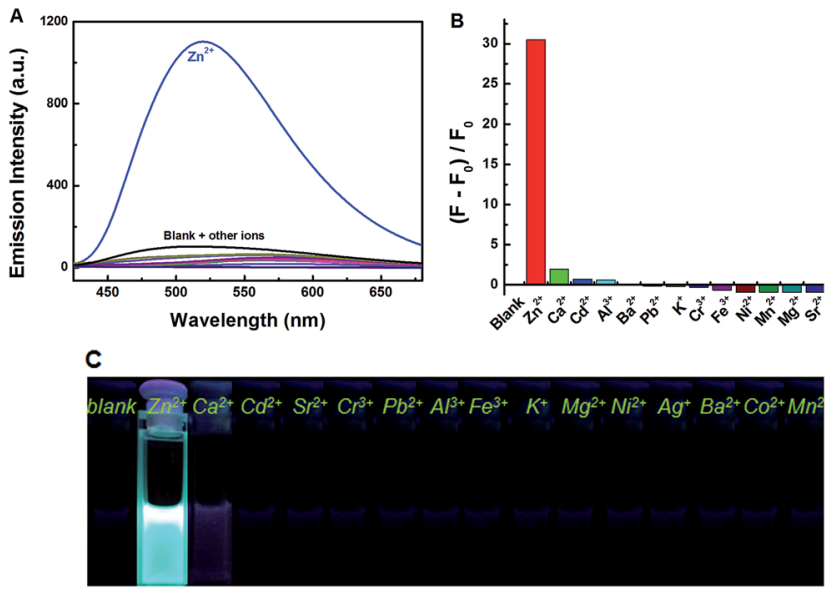

Fig. 3 Fluorescence changes of 10 induced by the addition of various metal ions (5.0 equiv.): (A) emission intensity in tetrahydrofuran; (B) emission intensity; $(C)$ photos of fluorescence.

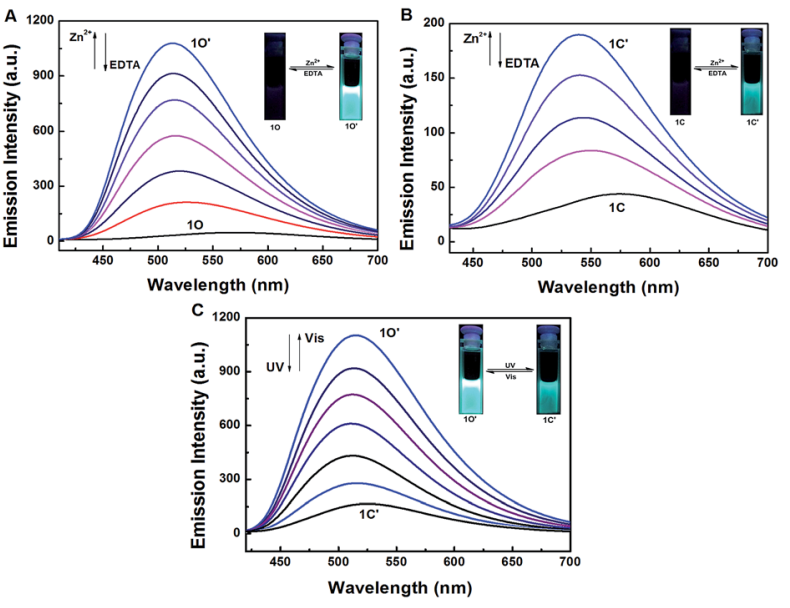

Fig. 4 Changes in fluorescence and color of 10 induced by $\mathrm{Zn}^{2+}$ / EDTA and light in tetrahydrofuran $\left(2.0 \times 10^{-5} \mathrm{~mol} \mathrm{~L}^{-1}\right)$ : (A) 10 induced by $\mathrm{Zn}^{2+} /$ EDTA, (B) $1 C$ induced by $\mathrm{Zn}^{2+} /$ EDTA, (C) $1 \mathrm{O}^{\prime}$ triggered by light.

recovered to that of $\mathbf{1 0}$ by adding an aqueous solution of excess EDTA $\left(0.1 \mathrm{~mol} \mathrm{~L}^{-1}\right)$ which possibly strips $\mathrm{Zn}^{2+}$ away from the cavity by the binding zone, indicating that the complexationdecomplexation reaction between 10 and $\mathrm{Zn}^{2+}$ was reversible. Similar to 10, the fluorescence of $1 \mathrm{C}$ could also be effectively modulated by $\mathrm{Zn}^{2+}$ in tetrahydrofuran. After adding 8.0 equiv. of $\mathrm{Zn}^{2+}$ to the solution of $1 \mathrm{C}$, its fluorescence intensity was enhanced by 4 folds and the emission peak was blue-shifted from 580 to $530 \mathrm{~nm}$ due to the formation of $\mathbf{1} \mathbf{C}^{\prime}$ (Fig. 4B). We also investigated the photochromism of $\mathbf{1 0}^{\prime}$. As shown in Fig. 4C, when the maximum intensity was reached, upon irradiation with $297 \mathrm{~nm}$ UV light, the emission intensity of $1 \mathbf{O}^{\prime}$ was quenched to $c a .15 \%$ due to the formation of $\mathbf{1} \mathbf{C}^{\prime}$, the fluorescent quantum yield of $\mathbf{1} \mathbf{C}^{\prime}$ was determined to be 0.028 . It can come back to that of $1 \mathbf{1}^{\prime}$ by irradiation with appropriate visible light and followed by a color change from bright aliceblue to powderblue. The irradiation with $\mathrm{UV} /$ vis light reaction between $\mathbf{1 0}^{\prime}$ and $\mathbf{1 \mathbf { C } ^ { \prime }}$ was also reversible.

To investigate the coordination mode of 10 with $\mathrm{Zn}^{2+}$, Job's plot analysis was performed according to the reported method. ${ }^{57}$ As shown in Fig. 5A, the maximum value was achieved when the molar fraction of $[\mathbf{1 0}] /\left([10]+\left[\mathrm{Zn}^{2+}\right]\right)$ was about 0.5 , demonstrating a $1: 1$ stoichiometry between 10 and $\mathrm{Zn}^{2+}$. Based on the $1: 1$ stoichiometry and fluorescence titration data, the association constant $\left(K_{\mathrm{a}}\right)$ of 10 with $\mathrm{Zn}^{2+}$ was calculated from the slope and intercept of the linear plot to be $7.17 \times 10^{3} \mathrm{~L}$ $\mathrm{mol}^{-1}(R=0.984)$ (Fig. 5B). The detection limit was calculated to be $1.28 \times 10^{-6} \mathrm{~mol} \mathrm{~L}^{-1}$ for $\mathrm{Zn}^{2+}$ (Fig. $5 \mathrm{C}$ ). To further confirm the coordination mode of $\mathbf{1 0}$ and $\mathrm{Zn}^{2+}$, ESI mass spectra were recorded. The ESI-MS peak at 699.1031 assigned to $\left[\mathbf{1 0}+\mathrm{Zn}^{2+}-\right.$ $3 \mathrm{H}]^{-}$(calcd 699.0241) was observed (Fig. S7 $\dagger$ ), providing strong evidence for the formation of a $1: 1$ complex between 10 and $\mathrm{Zn}^{2+}$. The proposed binding mode between 10 and $\mathrm{Zn}^{2+}$ was shown in Scheme 3.

\section{Application in logic circuit}

On the basis of the fact that the absorption and fluorescent intensity of the target diarylethene could be effectively 

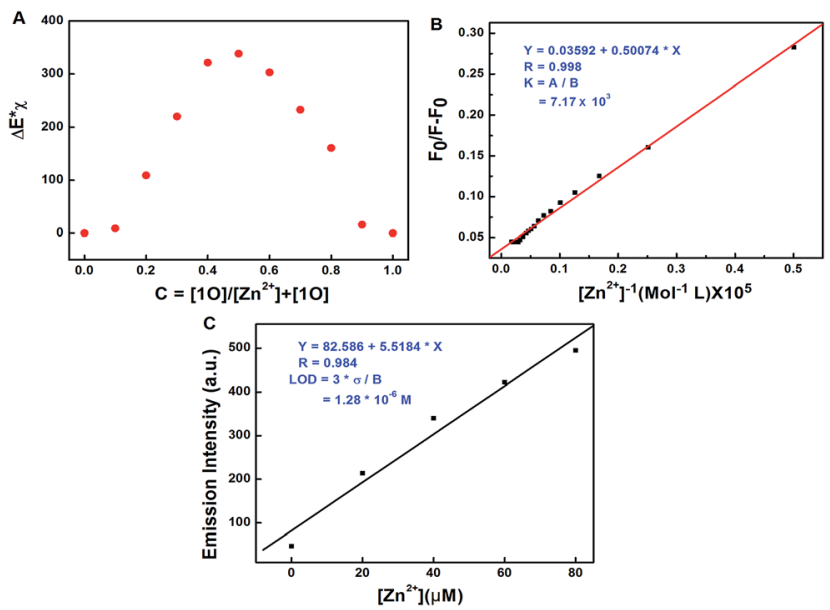

Fig. 5 (A) Job's plot showing the $1: 1$ complex of $10-\mathrm{Zn}^{2+}$ in tetrahydrofuran, (B) Hildebrand-Benesi plot based on the $1: 1$ for 10 , the binding constant of 10 with $\mathrm{Zn}^{2+}$ was calculated to be $7.17 \times 10^{3} \mathrm{~L}$ $\mathrm{mol}^{-1},(\mathrm{C})$ the limit of detection (LOD), LOD is $1.28 \times 10^{-6} \mathrm{~mol} \mathrm{~L}^{-1}$.

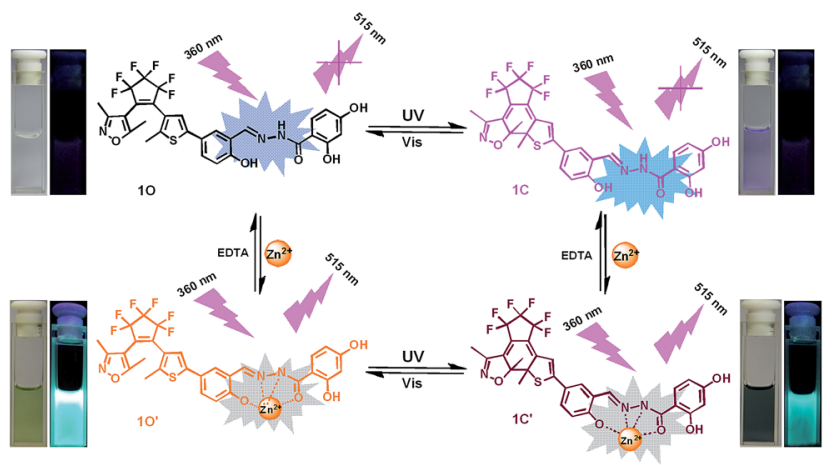

Scheme 3 Photochromism, color and fluorescence changes of 10 induced by $\mathrm{Zn}^{2+} /$ EDTA and lights.

modulated by $\mathrm{Zn}^{2+} /$ EDTA and light, a type of logic circuits was constructed by using light irradiation and $\mathrm{Zn}^{2+}$ /EDTA as the input signals. The fluorescence at $515 \mathrm{~nm}$ was used as an output signal. As shown in Fig. 6, the photochromic behaviors of $\mathbf{1 0}$ could be effectively modulated by $\mathrm{Zn}^{2+} /$ EDTA and UV/vis light. Thus, one logic circuit was constructed by using the combination of four input signals (In1: $297 \mathrm{~nm}$ UV light, In2: $\lambda>500 \mathrm{~nm}$ visible light, In3: $\mathrm{Zn}^{2+}$, and In4: EDTA) and an output

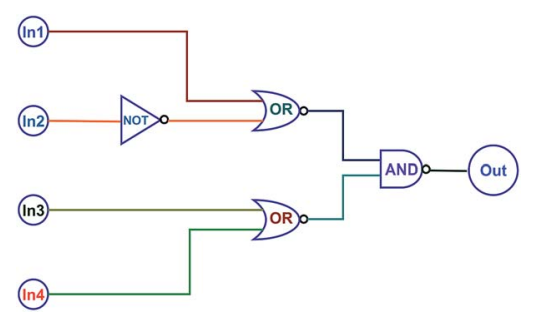

Fig. 6 The combinational logic circuits equivalent to the truth table give in Table 1, In1 (297 nm UV light), In2 ( $\lambda>500 \mathrm{~nm}$ light), In3 $\left(\mathrm{Zn}^{2+}\right)$, In4 (EDTA) and output $\left(\lambda_{\mathrm{em}}=515 \mathrm{~nm}\right)$.
Table 2 Truth table for all possible strings of four binary-input date and the corresponding output digit

\begin{tabular}{lllll}
\hline Inputs & & & & \\
\cline { 1 - 2 } $\operatorname{In} 1(\mathrm{UV})$ & $\operatorname{In} 2(\mathrm{vis})$ & $\operatorname{In} 3\left(\mathrm{Zn}^{2+}\right)$ & $\operatorname{In} 4$ (EDTA) & $\begin{array}{l}\text { Output } \\
\lambda_{\mathrm{em}}=515 \mathrm{~nm}\end{array}$ \\
\hline 0 & 0 & 0 & 0 & 0 \\
1 & 0 & 0 & 0 & 0 \\
0 & 1 & 0 & 0 & 0 \\
0 & 0 & 1 & 0 & 1 \\
0 & 0 & 0 & 1 & 0 \\
1 & 1 & 0 & 0 & 0 \\
1 & 0 & 1 & 0 & 1 \\
1 & 0 & 0 & 1 & 0 \\
0 & 1 & 1 & 0 & 1 \\
0 & 1 & 0 & 1 & 0 \\
0 & 0 & 1 & 1 & 0 \\
1 & 1 & 1 & 0 & 0 \\
1 & 1 & 0 & 1 & 0 \\
1 & 0 & 1 & 1 & 0 \\
0 & 1 & 1 & 1 & 0 \\
1 & 1 & 1 & 1 & 0
\end{tabular}

(fluorescence emission at $515 \mathrm{~nm}$ ). The four inputs and one output could be either "on" or "off" state with different Boolean values. When $297 \mathrm{~nm}$ light was employed, In1 was switched to "on" state with a Boolean value of "1". Similarly, In2 was "1" corresponding to irradiation with appropriate visible light $(\lambda>$ $500 \mathrm{~nm}$ ), In 3 was " 1 " corresponding to the addition of $\mathrm{Zn}^{2+}$, and In4 was " 1 " corresponding to the addition of EDTA. The emission intensity of 10 at $515 \mathrm{~nm}$ was regarded as the initial value and when the change of fluorescence intensity at $515 \mathrm{~nm}$ was 31 fold larger than the initial value, it was regarded as "on" state with a Boolean value of " 1 ". Otherwise, it was regarded as "off" state with a Boolean value of " 0 ". Upon the stimuli of different inputs, the diarylethene exhibited an on-off-on photochromic switching behavior. As a result, 10 could read a string of four inputs and write one output (Table 2).

\section{Conclusions}

In summary, a highly sensitive fluorescent "turn-on" sensor based on a photochromic diarylethene derivative with a salicylhydrazide unit was developed. It exhibited excellent photochromic properties, high selectivity and specificity toward $\mathrm{Zn}^{2+}$ over other metal ions. It could also be used as a naked-eye detector for $\mathrm{Zn}^{2+}$. Furthermore, the diarylethene showed excellent fluorescent switching behaviors with distinctive color changes in response to the combinational inputs of light and $\mathrm{Zn}^{2+}$. Based on these characteristics, a logic circuit was designed by the fluorescence intensity as the output signal with the inputs of $\mathrm{UV} / \mathrm{vis}$ lights and $\mathrm{Zn}^{2+} / \mathrm{EDTA}$. All these results will be helpful for the design and construction of new diarylethene derivatives with multi-addressable states and potential applications in fluorescent sensors for special ions.

\section{Conflicts of interest}

There are no conflicts of interest to declare. 


\section{Acknowledgements}

This work was supported by the Science Funds of Natural Science Foundation of Jiangxi Province (20171ACB20025); the Project of the Science Funds of Jiangxi Education Office (GJJ160795); the "5511" Science and Technology Innovation Talent Project of Jiangxi Province (20165BCB18015); the Project of Jiangxi Science and Technology Normal University Advantage Sci-Tech Innovative Team (2015CXTD002).

\section{Notes and references}

1 C. Andreini, L. Banci, I. Bertini, et al., J. Proteome Res., 2006, 5, 3173-3178.

2 P. S. Hariharan and S. P. Anthony, Anal. Chim. Acta, 2014, 848, 74-79.

3 A. Bhattacharyya, S. Ghosh, S. C. Makhal, et al., Spectrochim. Acta, Part A, 2017, 183, 306-311.

4 S. Enthaler, X. F. Wu, M. Weidauer, et al., Inorg. Chem. Commun., 2014, 46, 320-323.

5 Y. Han, C. Fu, J. Kuang, et al., Postharvest Biol. Technol., 2016, 116, 8-15.

6 H. Yang, Z. Y. Huang, J. Li, et al., Ecol. Indic., 2014, 45, 103109.

7 D. K. Khajuria, C. Disha, R. Vasireddi, et al., Mater. Sci. Eng., C, 2016, 63, 78-87.

8 C. Andreini, L. Banci, I. Bertini, et al., J. Proteome Res., 2006, 5, 3173-3178.

9 M. Saleem and K. H. Lee, RSC Adv., 2015, 5, 72150-72287.

10 X. Fang, H. Li, G. Zhao, et al., Biosens. Bioelectron., 2013, 42, 308-313.

11 M. Hosseini, A. Ghafarloo, M. R. Ganjali, et al., Sens. Actuators, B, 2014, 198, 411-415.

12 K. Vogt, J. Mellor, G. Tong, et al., Neuron, 2000, 26, 187-196.

13 A. Takeda, M. Nakamura, H. Fujii, et al., Metallomics, 2013, 5, 417-423.

14 B. Szewczyk, Front. Aging Neurosci., 2013, 5, 33.

15 S. Kumari, S. Joshi, T. C. Cordova-Sintjago, et al., Sens. Actuators, B, 2016, 229, 599-608.

16 S. Wang, X. Fei, J. Guo, et al., Talanta, 2015, 148, 229-236.

17 H. Nie, W. Yang, M. Yang, et al., Dyes Pigm., 2016, 127, 67-72.

18 S. Mukherjee, P. Mal and H. Stoeckli-Evans, J. Lumin., 2016, 172, 124-130.

19 H. N. Kim, W. X. Ren, J. S. Kim, et al., Chem. Soc. Rev., 2012, 41, 3210-3244.

20 C. Kar, M. D. Adhikari, A. Ramesh, et al., RSC Adv., 2012, 2, 9201-9206.

21 Y. L. Pak, K. M. K. Swamy and J. Yoon, Sensors, 2015, 15, 24374-24396.

22 M. Sohrabi, M. Amirnasr, H. Farrokhpour, et al., Sens. Actuators, B, 2017, 250, 647-658.

23 V. K. Gupta, A. K. Singh, L. K. Kumawat, et al., Sens. Actuators, B, 2016, 222, 468-482.

24 G. Kasirajan, V. Krishnaswamy, N. Raju, et al., J. Photochem. Photobiol., A, 2017, 341, 136-145.

25 B. Vidya, G. Sivaraman, R. V. Sumesh, et al., ChemistrySelect, 2016, 1, 4024-4029.
26 W. Wang, Y. N. Lei, Q. L. Liu, et al., Heterocycles, 2016, 92, 1204-1214.

27 Q. Li, Y. Zhang, Y. Jin, et al., RSC Adv., 2015, 5, 68815-68821.

28 J. An, M. Yan, Z. Yang, et al., Dyes Pigm., 2013, 99, 1-5.

29 A. Bhattacharyya, S. Ghosh, S. C Makhal, et al., Spectrochim. Acta, Part A, 2017, 183, 306-311.

30 N. Roy, A. Dutta, P. Mondal, et al., J. Fluoresc., 2017, 1-15.

31 L. Fan, J. Fluoresc., 2017, 1-7.

32 T. Liu, J. Yin, Y. Wang, et al., J. Electroanal. Chem., 2016, 783, 304-307.

33 C. Wu, Y. Ikejiri, J. L. Zhao, et al., Sens. Actuators, B, 2016, 228, 480-485.

34 X. Lu, W. Zhu, Y. Xie, et al., Chem.-Eur. J., 2010, 16, 8355-8364. 35 M. Li, H. Y. Lu, R. L. Liu, et al., J. Org. Chem., 2012, 77, 36703673.

36 S. Zhu, J. Zhang, J. Janjanam, et al., J. Mater. Chem. B, 2013, 1, 1722-1728.

37 S. C. Burdette, G. K. Walkup, B. Spingler, et al., J. Am. Chem. Soc., 2001, 123, 7831-7841.

38 L. Wang, W. Qin, X. Tang, et al., Org. Biomol. Chem., 2010, 8, 3751-3757.

39 T. Mistri, M. Dolai, D. Chakraborty, et al., Org. Biomol. Chem., 2012, 10, 2380-2384.

40 E. Hao, T. Meng, M. Zhang, et al., J. Phys. Chem. A, 2011, 115, 8234-8241.

41 X. Zhou, P. Li, Z. Shi, et al., Inorg. Chem., 2012, 51, 92269231.

42 C. Gao, X. Jin, X. Yan, et al., Sens. Actuators, B, 2013, 176, 775781.

43 Y. Li, J. Wu, X. Jin, et al., Dalton Trans., 2014, 43, 1881-1887. 44 N. Roy, A. Dutta, P. Mondal, et al., Sens. Actuators, B, 2016, 236, 719-731.

45 W. K. Dong, X. L Li, L. Wang, et al., Sens. Actuators, B, 2016, 229, 370-378.

46 R. Pardo, M. Zayat and D. Levy, Chem. Soc. Rev., 2011, 40, 672-687.

47 F. Liu and K. Morokuma, J. Am. Chem. Soc., 2013, 135, 1069310702.

48 J. Zhang, Q. Zou and H. Tian, Adv. Mater., 2013, 25, 378-399.

49 A. Uyama, S. Yamazoe, S. Shigematsu, et al., Langmuir, 2011, 27, 6395-6400.

50 H. Tian and S. Yang, Chem. Soc. Rev., 2004, 33, 85-97.

51 M. Irie, T. Fukaminato, K. Matsuda, et al., Chem. Rev., 2014, 114, 12174-12277.

52 Z. X. Li, L. Y. Liao, W. Sun, et al., J. Phys. Chem. C, 2008, 112, 5190-5196.

53 C. Fan, S. Pu, G. Liu, et al., J. Photochem. Photobiol., A, 2008, 197, 415-425.

54 Y. Fu, Y. Tu, C. Fan, et al., New J. Chem., 2016, 40, 8579-8586. 55 J. S. Wu, W. M. Liu, X. Q. Zhuang, et al., Org. Lett., 2007, 9, 33-36.

56 P. S. Hariharan and S. P. Anthony, RSC Adv., 2014, 4, 4156541571.

57 H. A. Benesi and J. H. Hildebrand, J. Am. Chem. Soc., 1949, 71, 2703-2707.

58 S. Pu, Z. Tong, G. Liu, et al., J. Mater. Chem. C, 2013, 1, 47264739. 